\title{
PENGINTEGRASIAN MODEL LEADERSHIP MENUJU MODEL YANG LEBIH KOMPREHENSIF DAN PARSIMONI
}

\author{
Miswanto \\ Sekolah Tinggi Ilmu Ekonomi YKPN Yogyakarta \\ e-mail: miswanto_miswanto@yahoo.com
}

\begin{abstract}
Through leadership models offered by Locke et. al (1991) we can say that whether good or not the vision of leaders in the organization is highly dependent on whether good or not the motives and traits, knowledge, skill, and abilities owned leaders. Then, good or not the implementation of the vision by the leader depends on whether good or not the motives and traits, knowledge, skills, abilities, and the vision of the leaders. Strategic Leadership written by Davies (1991) states that the implementation of the vision by using strategic leadership, the meaning is much more complete than what has been written by Locke et. al. in the fourth stage of leadership. Thus, aspects of the implementation of the vision by Locke et al (1991) it is not complete implementation of the vision according to Davies (1991). With the considerations mentioned above, this article attempts to combine the leadership model of the Locke et. al and strategic leadership of the Davies. With this modification is expected to be an improvement model ofleadership is more comprehensive and parsimony.
\end{abstract}

Keyword: leadership, strategik, visi, motif, sifat, pengetahuan, keterampilan, kemampuan

\section{PENDAHULUAN}

Penulis sangat tertarik terhadap karya ilmiah yang berjudul "The Esence ofLeadership" (Locke et al., 1991). Mereka mengawali pembahasannya dengan menjelaskan apa itu leadership. Kemudian menjelaskan apa yang menjadi perbedaan antara leadership dan manajemen. Dalam membahas teori leadership, Locke, et al. ini mengupas secara ringkas teori leadership transaksional dan transformasional. Kemudian dalam pembahasan berikutnya dari bab pertama sampai dengan bab terakhir, intinya Locke et.al. menawarkan suatu pokok-pokok atau garis besar leadership yang terangkum dalam suatu model yang disebut leadership model yang disusun dari pengintegrasian kerja leadership. Ilustrasi leadership model dapat dilihat di Gambar 1 (Locke et al., 1991, p. 7).

Leadership seperti pada Gambar 1 berisi empat bagian, yaitu: 1) motive dan trait, 2) pengetahuan, visi, dan kemampuan, 3) visi, dan 4) implementasi visi. Bagian 1, motive dan trait adalah karakteristik leader efektif yang didapatkan untuk membedakan dari bukan leader. Motif leader efektif ada dua macam: penggerakan (drive) dan pemotivasian leadership. Motif adalah: penggerakan (drive) yang berkaitan dengan upaya dalam: pencapian, ambisi, energi, tenacity, dan inisiatif. Motivasi leadership meliputi keinginan untuk mempengaruhi orang lain.

Bagian 2, pengetahuan, keterampilan, dan kemampuan yang terkait dengan leadership efektif, yang meliputi: 1) penguasaaan pengetahuan industri, teknologi, dan lingkungan organisasi, 2) berbagai keterampilan yang meliputi keterampilan orang (people skill), keterampilan manajemen (managerial skill), dan 3) kemampuan meliputi kemampuan kognitif dan kemampuan intelegensia. Bagian 3, visi adalah komponen pokok. Bagian 
4, implementasi visi adalah sebagai suatu kebutuhan keberhasilan leadership. Visi yang tidak diimplementasikan tetap hanya merupakan mimpi. Oleh karena itu, leader efektif melakukan langkah untuk menjamin bahwa visi diterjemahkan ke dalam tindakan spesifik, yang biasanya dicapai dengan bantuan manajer dan bawahannya. Tindakan implementasi visi memiliki enam kategori, yaitu: 1) membuat struktur organisasi, 2) menyeleksi, melatih, dan mengangkat karyawan, 3) memotivasi bawahan, 4) mengelola informasi, 5) membangun tim, dan 6) melakukan perubahan, inovasi, dan menghadapi risiko.

Bagian 1

Motif and Traits

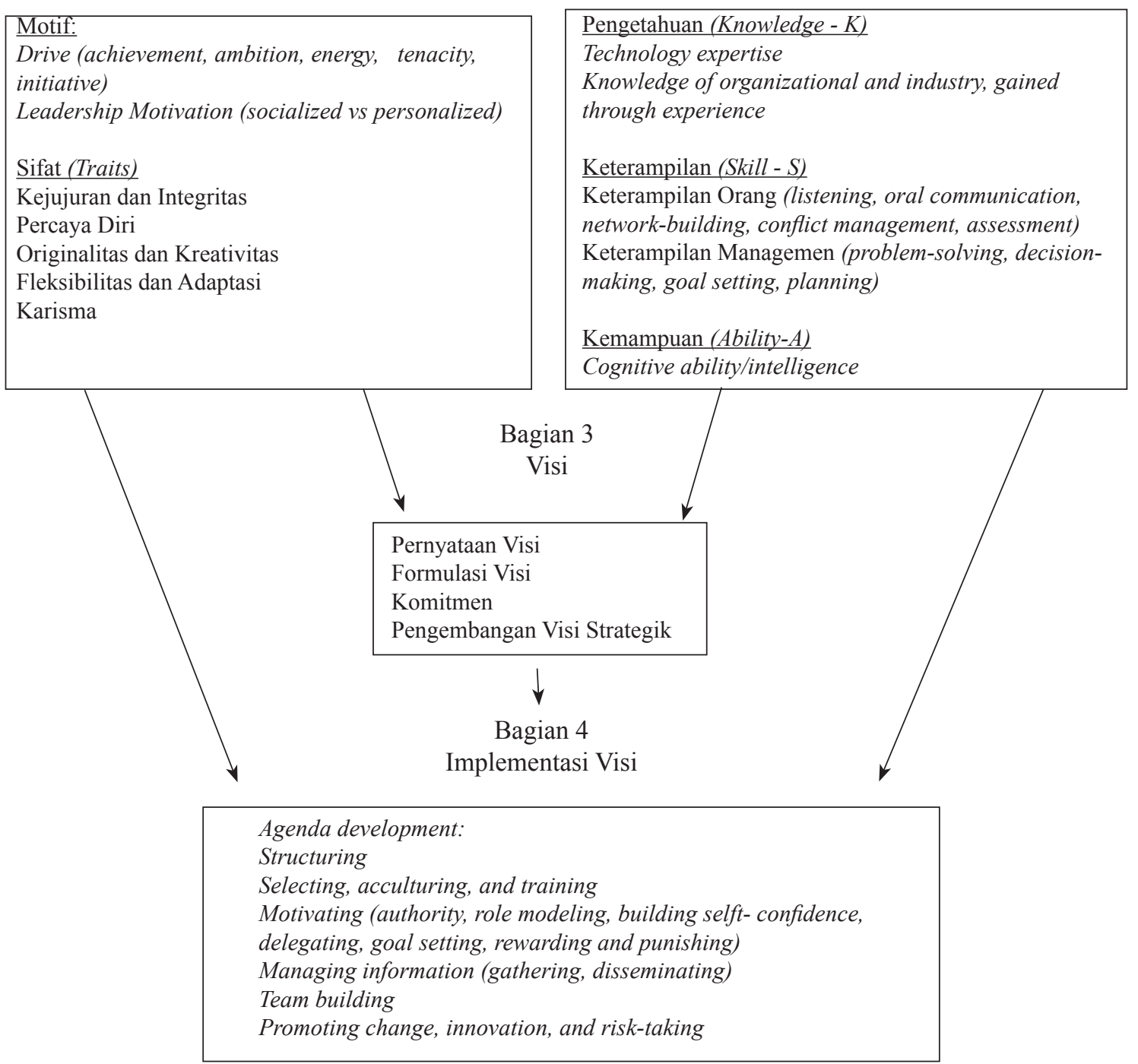

Bagian 2

KSA exe organizational and industry, gained

Keterampilan (Skill - S)

Keterampilan

making, goal setting, planning)

Kemampuan (Ability-A)

Cognitive ability/intelligence

Gambar 1. Model Leadership (Locke et.al., 1991, p. 7) 
Dalam artikel ini, penulis akan membahas model leadership-nya Locke et al. (1991) dengan mengupas isi model leadership tersebut, dan perbaikan terhadap model tersebut untuk menuju model yang lebih komprehensip dan parsimoni. Adapun urut-urutan pembahasannya adalah pertama, relevansi model leadership tersebut dengan pengetahuan leadership. Kedua, overview terhadap isi model leadership-nya Locke et al. (1991) dan analisis perspektif. Ketiga, perspektif lain dalam pengintegrasian teori leadership. Keempat (terakhir), perbaikan model leadership yang lebih komprehensip dan parsimoni.

\section{RELEVANSI DENGAN PENGETAHUAN LEADERSHIP}

Dalam kajian-kajian teori organisasi, ada berbagai buku ilmiah mengenai teori-teori leadership terutama dari buku yang ditulis, Pfeffer (1982) dan Yukl (1989). Di samping buku, ada berbagai karya ilmiah berupa artikel mengenai leadership. The Essence of Leadership (Locke, et. al) ini disusun juga merujuk dari berbagai buku dan artikel-artikel mengenai teori leadership dan motivasi. Dengan demikian, isinya juga sejalan dengan teori-teori yang ada. Apa yang dinyatakan di karya ilmiah tersebut yang berupa buku tersebut tidak melepaskan sumbernya dari mana sehingga mudah sekali untuk melihat kesesuaian antara isi buku ini dan teori-teori leadership dan motivasi yang dikutip dan yang ada. Bahkan buku ini mempunyai kelebihan dalam hal penyampaian. Teori-teori dan hasil riset mengenai leadership dan motivasi yang telah dikutip oleh penulis buku ini dapat ditulis kembali dalam bahasa penyampaian yang sangat menarik. Dengan menggunakan bahasa yang sederhana, kalimat yang pendek-pendek, dan alur kata yang bagus, maka maksud dari Locke, et al. yang telah disampaikan melalui buku ini mudah dicerna dan dipahami.

Dalam buku dan artikel-artikel yang lain, pembahasan teori-teori leadership, misalnya teori sifat, teori perilaku, teori situasional, dan teori leadership yang kontemporer sering kali tidak saling berkaitan dan penulisnya tidak mencoba mengkaitkan dengan teoriteori yang lain misalnya dengan teori motivasi dan teori managerial yang relevan. Locke et al. (1991) mencoba mengintegrasikan berbagai teori leadership dan yang terkait dengan teori leadership, misalnya teori-teori motivasi yang ada, dan juga teoriteori yang terkait dengan leadership lainnya. Pengintegrasian berbagai teori tersebut yang kemudian disederhanakan dalam suatu model yang disebut: leadership model. Hebatnya lagi, Locke et al. (1991) mencoba merangkai antara teori yang satu dengan yang lain yang hal ini bisa dilihat dalam tahap-tahapan yang ada di leadership model. Dalam Gambar 1 dapat dilihat bahwa tahap 1 (Motives dan Traits) mempengaruhi tahap 3 (Visi) dan tahap 4 (Implementasi Visi). Kemudian tahap 2 (KSA - Knowledge, Skill, dan Ability) dapat mempengaruhi tahap 3 (Visi) dan tahap 4 (Implementasi Visi). Dengan kata lain bahwa tahap 3 (visi) dipengaruhi oleh tahap 1 (Motive dan Trait) dan tahap 2 (KSA). Kemudian tahap 4 (Implementasi) dipengaruhi oleh tahap 1 (Motive dan Trait), tahap 2 (KSA), dan dipengaruhi oleh tahap 3 (Visi)

Melalui leadership model yang ditawarkan oleh Locke et al. (1991) dapat dikatakan bahwa baik tidaknya visi leader dalam menjalankan organisasi sangat tergantung pada baik tidaknya motif dan sifat (trait), pengetahuan (knowledge), keterampilan (skill), dan kemampuan (ability) yang dimiliki leaders. Kemudian, baik tidaknya implementasi visi yang dilakukan oleh leader juga tergantung pada baik tidaknya motif dan sifat (trait), pengetahuan (knowledge), keterampilan (skill), kemampuan (ability), dan visi yang dimiliki oleh leader. 


\section{OVERVIEW DAN ANALISIS PERSPEKTIF}

Dalam mencoba membahas atau me-review karya ilmiah Locke et al. (1991) dengan beberapa analisis perspektif, penulis artikel ini akan fokus dengan menggunakan buku Leadership in Organization (Yukl, 1989), Strategic Leadership (Davies, 1991), Organization and Organization Theory (Pfeffer, 1982), Theories of Organizational Behavior (Miner, 1980), dan dengan beberapa artikel tentang leadership. Perspektif leadership menurut Locke, et. al. dapat diikuti dengan mudah melalui leadership model yang mereka tuliskan di bukunya. Untuk memudahkan dalam melakukan overview dan analisis perspektif, urut-urutanya analisis perspektifnya mengunakan tahap-tahapan yang ada di leadership model yang terdiri dari empat tahap, yaitu: 1) motif dan sifat, 2) pengetahuan, keterampilan, dan kemampuan, 3) visi, dan 4) pengimplementasian visi.

Perspektifpada Bagian 1 mengenai teori motif dan sifat yang disampaikan oleh Loecke, et.al., berbeda dalam penyajian tetapi pada hakekatnya sama dengan perspektif yang disampaikan oleh Yukl (1989, p. 257-261) dalam artikelnya yang berjudul Managerial Leadership: A Review of Theory and Research, dan juga sama dengan yang disampaikan oleh Jago (1982, p. 317) dalam artikelnya yang berjudul Leadership: Persepctives in Theory and Rsearch. Perspektif Bagian 2 mengenai pengetahuan, keterampilan, dan kemampuan yang disampaikan oleh Locke, et al. ini, berbeda dalam penyajian, tetapi ada kesamaan perspektif dengan yang disampaikan oleh Yukl (1989) dalam bukunya yang berjudul Leadership in Organizations. Pada Bagian 2 ini, meskipun berbeda dalam penyajian, yang disampaikan Locke et al. ini juga ada kesamaan persepektif dengan yang disampaikan oleh Miner (1980, p. 168-193, 354-371) dan Pfeffer (1982, p. 41-71), karena referensi yang digunakan antara kedua buku tersebut relatif sama.

Pada Bagian 3 mengenai visi yang isinya tentang: pernyataan visi, merumuskan visi, meningkatkan komitmen bawahan, dan pengembangan, adalah berbeda dalam penyajian, tetapi sebetulnya juga ada kesamaam perspektif dengan bukunya Miner (1980), Pfeffer (1982), Yukl (1989), dan Pinder (1984). Bedanya penyajian adalah Locke dalam menyajikan Bagian 2 ini lebih ringkas daripada buku-buku yang lain dan melihat dari perspektif visi, sedangkan isinya sama dengan buku-buku yang lain. Bagian 4 dalam leadership model ini, yaitu tentang implementasi visi, yang isinya ada kemiripan dengan bukunya yang berjudul Strategic Leadership (Davies, 1991). Karena sifat dari bukunya Locke et.al. hanya berupa garis besar atau pokoknya, pembahasan pada Bagian 4 ini tidak selengkap pembahasan implementasi yang dilakukan oleh Davies.

Agar ada gambaran yang lebih rinci mengenai perspektif leadership yang disampaikan oleh Locke (1991), maka leadership model yang terdiri dari empat tahap yaitu: 1) motif dan sifat, 2) pengetahuan, keterampilan, dan kemampuan, 3) visi, dan 4) pengimplementasian visi, akan dijelaskan lebih rinci. Berikut ini adalah penjelasan yang lebih rinci pada masing-masing tahap dalam leadership model.

\section{Tahap 1 Leaderhip Model: Motif dan Sifat (Trait)}

Memiliki motif dan sifat adalah prakondisi untuk individu menjadi leader yang efektif. Motif adalah berupa drive dan motivasi leadership, dan sifat adalah berupa integritas, jujur dan percaya diri. Ada beberapa bukti bahwa sifat-sifat lain seperti originalitas, fleksibilitas, dan karisma adalah terkait pada leadership yang efektif, tetapi bukti yang dimaksud belum begitu cukup.

Motif. Beberapa motif bersifat umum (general), dan motif tersebut menggerakkan orang untuk bertindak melintasi berbagai situasi yang berbeda. Sejumlah motif umum 
didapatkan dalam leader yang berhasil. Drive, motif jenis pertama, dimaksudkan disini untuk mencakupi berbagai yang terkait meskipun motifnya tidak sama. Drive tersebut terdiri dari: 1) pencapaian (achievement), 2) ambisi, 3) energi, 4) tenacity, dan 5) inisiatif. Pencapaian, drive yang pertama, adalah salah satu dari drive. Pencapai yang tinggi menghasilkan kepuasan dengan tugas yang menantang yang dapat diselesaikan dengan baik, dengan pencapaian standar unggul, dan dengan mengembangkan cara-cara melakukan yang lebih baik. Ahli psikologi Bernard Bass (1990) menilai 28 macam kajian dan mendapatkan bukti bahwa keinginan untuk pencapaian adalah suatu faktor motivasi yang penting antar leader-leader yang efektif. Ambisi sebagai jenis drive yang kedua mensyaratkan bahwa leader harus mempunyai keinginan untuk maju ke depan dalam karir dan membuat divisi dan perusahaannya tumbuh dan berkembang. Untuk maju dan berkembang, leader harus aktif mengambil langkah-langkah untuk tampil sebagai penggerak dan penentu.

Energi, drive yang ketiga, adalah perlu untuk leader untuk menopang upaya pencapaian yang tinggi dan maju ke depan dalam organisasi. Kerja yang begitu intensif dan lama mensyaratkan individu mempunyai fisik, mental, dan emosi yang tangguh. Tenacity, drive yang keempat, artinya bahwa leader harus persisten yang tidak mengenal lelah dalam aktivitasnya, khususnya dalam mengkomunikasikan visinya kepada karyawan. Bukti yang dapat dipertimbangkan menunjukkan bahwa leader efektif harus memiliki tenacity yang berlimpah. Inisiatif, drive yang terakhir, adalah motif yang membuat leader efektif untuk melakukan tindakan proaktif. Leader membuat pilihan dan melakukan sesuatu yang mengarahkan untuk perubahan yang produktif daripada hanya bereaksi pada kejadian atau menunggu sesuatu apa yang terjadi.

Setelah drive, motif yang kedua adalah motivasi leadership. Leader efektif harus mau mengarahkan. Motivasi leadership meliputi keinginan untuk mempengaruhi yang lain. Motivasi leadership sering disamakan dengan kebutuhan pada kekuasaan (power). Orang dengan motivasi leadership yang tinggi berpikir banyak tentang bagaimana mempengaruhi orang lain, atau mencapai posisi wewenang yang lebih tinggi.

Sifat. Sifat (trait) berbeda dengan motif, yang mana sifat adalah pola tindakan yang dapat diobservasi atau cara-cara yang biasa digunakan dalam berpikir. Motif dapat mendasari sifat-sifat, tetapi tidak ada hubungan satu sama lain antara sifat dan motif. Sifat yang ada dapat merefleksikan motif ganda, motif yang ada dapat mendasari sejumlah sifat.

Ada sejumlah bukti bahwa leadership efektif adalah ditandai dengan sifat-sifat jujur, integritas, dan percaya diri. Ada bukti yang kurang konklusif yang terkait dengan peran sifat kreatif, fleksibilitas, dan karisma. Studi menunjukkan bahwa tanpa jujur dan integritas, perusahaan yang dipimpin oleh leader akan runtuh perlahan-lahan. Integritas didefinisikan sebagai adanya kesesuaian antara kata dan perbuatan.

Percaya diri, sifat kedua leader, merupakan sifat penting leadership berhasil. Percaya diri memainkan peran penting dalam pengambilan keputusan dan dalam memperoleh kepercayaan dari orang lain. Studi yang dikutip oleh Locke, et al. dalam bukunya ini menunjukkan bahwa leader mempunyai tingkat percaya diri lebih tinggi daripada bukan leader.

Originalitas dan kreativitas merupakan sifat ketiga leader. Ada beberapa alasan untuk meragukan originalitas dan kreativitas sebagai sifat leadership. Riset terbatas yang telah dilakuka pada kreativitas telah menghasilkan hasil positif, tetapi kreativitas jarang disebutkan sebagai sifat penting dalam studi kualitatif leader. 
Kreativitas membantu leadership yang efektif dalam situasi tertentu, misalnya ketika entrepreneur melakukan pembuatan barang atau jasa baru, atau ketika membangun perusahaan mulai dari bawah. Konsep yang terkait dengan originalitas adalah imajinasi, yaitu kemampuan untuk memvisualisasikan apa yang mau dilakukan, dan imajinasi adalah penting untuk pengembangan visi.

Fleksibilitas dan adaptasi merupakan sifat keempat leader. Leader efektif harus fleksibel untuk menghadapi tantangan perubahan yang drastis dan cepat. Fleksibilitas dikaitkan dengan kemampuan leadership dalam sejumlah kajian yang dilakukan oleh Bass. Dengan menggunakan kemampuannya di berbagai hal, pentingnya fleksibilitas seperti kemampuan untuk berpartisipasi dalam proses perubahan dan untuk melaksanakan yang lebih kreatif.

Karisma adalah sifat kelima atau yang terakhir pada leader. Ada yang berbendapat bahwa orang yang karismatik adalag orang yang lebih memberikan dorongan daripada yang lain. Karisma akan nampak ketika leader berkomunikasi, khusunya ketika leader sedang memberikan kata-kata yang inspiratif untuk mendorong bawahan.

\section{Tahp 2 Leadership Model: Pengetahuan, Keterampilan, dan Kemampuan}

Meskipun memiliki motif dan sifat belum dengan sendirinya membuat leader efektif. Motif dan sifat dapat membantu individu memperoleh pengetahuan dan keterampilan untuk memformulasikan visi leader dan mengimplementasikan. Kemampuan (abilitity), khusunya kemampuan kognitif memainkan peran penting dalam leadership.

Pengetahuan (Knowledge). Keahlian teknologikal sering memfasilitasi kemampuan leader untuk mengarahkan organisasi. Bass mendapat suatu kesimpulan bahwa pengetahuan yang terspesialisasi adalah kontributor kunci pada leadership.

Dalam suatu studi leadership disimpulkan bahwa menjadi orang yang ahli (expert) adalah penting untuk leadership yang efektif, dan keahlian tersebut dapat dihasilkan disamping melalui pendidikan juga dapat dihasilkan melalui pengalaman. Pengetahuan tentang industri dan organisasi dapat diperoleh melalui pengalaman yang lalu. Dengan pengalaman yang lalu, leader dapat membuat keputusan rasional secara cepat. Pengalaman leader adalah dasar pengetahuannya yang dapat menstimuli intelektualnya dan memperluas pemahaman bahwahannya terhadap persoalan organisasi.

Keterampilan (Skill). Keterampilan leader dibedakan menjadi dua, yaitu: keterampilan interpersonal dan keterampilan manajemen. Interpersonal skill merupakan keterampilan yang digunakan dalam berinteraksi antara leader dan pengikutnya (bawahan). Keterampilanm interpersonal leader adalah penting dalam proses penginspirasian orang lain ke arah pengimplementasian visi. Leader yang berhasil secara umum mempunyai keterampilan interpersonal yang sangat kuat, mengahadapi orang lain dengan baik, dan pandai berdiplomasi dan bijaksana. Faktor interpersonal yang mempengaruhi kepuasan bawahan dan efektivitas leadership adalah sangat dipertimbangkan untuk dilakukan oleh leader.

Keterampilan interperonal yang lain adalah juga penting untuk dimiliki leader, yaitu keterampilan mengkomunikasikan visi. Keterampilan tersebut meliputi keterampilan: mendengarkan, komunikasi lisan, membangun jaringan (network), manajemen konflik, dan menilai diri dan orang lain.

Selain keterampilan interpersonal, keterampilan manajemen juga harus dimiliki oleh leader. Salah satu keterampilan manajemen adalah keterampilan administratif. Keterampilan administratif adalah penting untuk menjalankan fungsi manajemen yang 
memfasilitasi aktivitas hari ke hari dari suatu organisasi. Keterampilan tersebut meliputi pemecahan masalah, pengambilan keputusan, penentuan tujuan, dan perencanaan. Keahlian administratif tidak sama dengan gaya manajemen. Keahlian administratif adalah kompetensi yang memberikan leader untuk melaksanakan tugas dengan gaya apapun yang leader pilih. Keterampilan administratif cenderung untuk mengarahkan bawahan ke penentuan tujuan yang lebih tinggi dan realistik.

Kemampuan (Ability). Kemampuan kognitif(intelgensi) adalah suatu aset pada leader sebab leader harus mengumpulkan, mengintegrasikan, dan mengintepretasikan sejumlah infromasi. Leader membutuhkan kemampuan yang tinggi untuk memformulasikan strategi yang cocok, memecahkan masalah, dan membuat keputusan yang benar. Leader sering dikarakteristikkan seperti orang yang cerdas dan dikonsepsikan orang yang ahli.

\section{Tahap 3 Leadership Model: VISI}

Melalui penciptaan visi, leader mengintegrasikan dan mengarahkan usaha-usaha semua anggota organisasi. Leader efektif mengenali pentingnya visi. Segala sesuatunya, leader harus melakukan sesuai dengan visi atau mendukung visi. Fungsi utama leader adalah menetapkan visi untuk organisasi dan mengkomunikasikan visi dengan cara yang menarik kepada bawahan.Visi didefinisikan sebagai gambaran yang akan datang yang unik dan ideal. Hicman dan Silva menguraikan visi sebagai perjalanan mental dari yang diketahui ke yang tidak diketahui, menciptakan yang akan datang dari gambaran atau ilustrasi fakta sekarang, harapan-harapan, mimpi-mimpi, bahaya-bahaya, dan peluangpeluang. Langkah-langkah dalam menyusun visi adalah 1) pernyataan visi, 2) formulasi visi, 3) meningkatkan komitmen, dan 4) mengembangkan visi.

Pernyataan visi adalah langkah pertama dalam visi. Visi yang komplek akan menjadi masalah karena visi yang komplek tidak dapat dikomunikasikan dengan singkat dan jelas kepada bawahan dan customer. Meskipun visi diumpamakan seperti bola salju, pernyataan visi sebaiknya yang menginspirasikan dan memotivasi, yaitu yang memiliki karakteristik: brevety, clarity, abstractness, challenge, future-orientation, stability, dan desirabality.

Langkah kedua dalam visi adalah formulasi visi. Meskipun akhirnya leader memformulasikan visi perusahaan, leader sering mencari informasi dari sumber-sumber dari luar organisasi. Setiap langkah proses formulasi dapat dipengaruhi oleh informasi dan opini dari pengetahuan individu-individu. Formulasi visi memerlukan: 1) pengumpulan informasi, 2) memproses informasi, 3) mengkonsepsualisasikan visi, dan 4) mengevaluasi visi.

Meningkatkan komitmen adalah langkah ketiga visi. Tantangan leader berikutnya adalah menanamkan visi kepada yang lain. Sebelum leader dapat berharap untuk mencapai visi, leader harus bekerja mengklarifikasi visi pada bawahannya dan membangun komitmen pada mereka. Tanpa komitmen bawahan, pencapian visi tidak dapat dilaksanakan. Komitmen dapat diperoleh melalui proses komunikasi. Pengkomunikasian pesan visi adalah penting sebab tanpa komunikasi efektif, pesan tidak dapat sampai ke penerima.

Pengembangan visi strategik merupakan langkah visi yang terakhir. Visi menunjukkan arah tujuan organisasional yang relatif stabil. Pencapaian tujuan membutuhkan perencanaan. Visi strategik adalah penting untuk pencapaian tujuan yang utama. Oleh karena itu, visi strategik adalah strategic trust bagi organisasi. 


\section{Tahap 4 Leadership Model: Implementasi Visi}

Leader menggunakan motif, sifat, dan keterampilannya untuk mengaktualisasikan visi dalam realitas dengan melakukan tahap-tahap untuk menerjemahkan visinya ke suatu agenda, yaitu daftar sesuatu yang akan dikerjakan. Agenda adalah mengkaitkan antara visi dan implementasinya. Serangkaian perkembangan dari visi ke agenda dilanjutkan ke kebijakan dan prosedur. Kebijakan dan prosedur memerlukan implementasi visi yang terdiri dari enam kategori, yaitu 1) struktur, 2) seleksi, pelatihan, dan penggajian karyawan, 3) memotivasi karyawan, 4) mengelola informasi, 5) membangun tim, dan 6) melakukan perubahan.

Struktur. Struktur, kategori pertama implementasi visi, adalah penting untuk menentukan bagaimana dan apakah visi organisasi akan dapat tercapai. Tom Peter (1987) menekankan secara sederhana pentingnya karakteristik struktur. Dia menekankan pada lapisan-lapisan manajemen dan birokrasi excessive -- yang melebihi daripada semestinya -- yang menjadi masalah utama dalam organisasi.

Seleksi, Pembudayaan, dan Pelatihan. Kategori kedua implementasi yang kedua adalah seleksi, pembudayaan, dan pelatihan karyawan. Seleksi dan pengembangan pengikut atau karyawan yang mampu dan mau untuk bekerja dalam upaya mencapai visi organisasi adalah tugas leadership yang penting sebab leader dalam menjalankan tugasnya tergantung pada pengikutnya untuk mencapai tujuan.

Pembudayaan adalah proses yang mana budaya organisasi dan visi ditanamkan ke anggota individu. Pelatihan diperlukan untuk membantu anggota organisasi belajar bagaimana mereka menyesuaikan dengan visi dan tujuan organisasi, terutama tanggung jawab dan kewajiban posisi mereka, apa yang diharapkan oleh mereka, dan bagaimana kinerja mereka akan diukur. Pembudayaan dan pelatihan dapat dikombinasikan dalam beberapa hal. Sesi pelatihan memberikan peluang yang baik untuk mengajari nilai dan visi. Program pelatihan yang baik harus dilihat sebagai peluang utama untuk menentukan nilai organisasi. Leader perlu menentukan area (wilayah) dimana pelatihan diperlukan dan memberikan pelatihan untuk mengembangkan kemampuan karyawan dalam bekerja.

Pemotivasian. Pemotivasian adalah kategori ketiga. Agar leader dapat mencapai visinya, leader harus memotivasi yang lain untuk bekerja dengan hasil yang baik. Karyawan organisasi adalah aset (kekayaan) yang paling berharga dan melalui merekalah cara yang terbaik untuk mencapai tujuan organisasi. Tugas pemotivasian adalah membangkitkan antusiasme untuk kerja, berkomitmen pada sasaran tugas, memenuhi dengan pesanan dan pemintaan.

Leader efektif memotivasi pengikutnya dengan cara menggunakan: 1) wewenang formal, 2) role modeling, 3) membangun percaya diri, 4) menciptakan tantangan melalui penentuan tujuan (goal-setting), 5) pendelegasian, dan 6) penggajian dan hukuman. Wewenang formal, cara pertama, melekat pada posisi leader dalam hirarkhi formal organisasi dan weweang formal dengan sendirinya menjadi sumber pemotivasian pada pengikutnya. Kenyataan bahwa leader mempunyai tingkat yang lebih tinggi daripada pengikutnya. Role modelling adalah cara kedua yang dapat digunakan leader untuk memotivasi yang lain agar bekerja merealisasikan visi. Leader menjalani role model yang berarti menjadi simbol yang nampak dari apa yang diinginkan oleh para pengikutnya. Dengan demikian, leader harus memberikan contoh dalam pengimplementasian visi.. Apabila leader dapat berkata dengan fasih tentang visi dan nilai, tetapi perilakunya tidak konsisten dengan pernyataannya, maka orang tidak akan respek terhadap leader tersebut. 
Leader efektif harus menggunakan role model tidak hanya untuk menunjukkan pengikutnya apa yang diharapkan dari mereka tetapi untuk mengkomunikasikan secara jelas kepada pengikutnya. Dengan demikian, leader harus memiliki komitmen yang baik. Role modeling adalah teknik yang sangat bagus untuk menanamkan dan menguatkan budaya organisasional.

Membangun percaya diri, cara memotivasi ketiga, menanamkan pada pengikut suatu keyakinan bahwa mereka mempunyai kemampuan melaksanakan pekerjaannya dengan berhasil dan berkontribusi pada pencapaian visi organisasi. Leader harus membantu bahwa mereka dapat efektif dan tujuan mereka dapat tercapai. Karena leader mempunyai kepercayaan diri, maka leader mempunyai keunggulan ketika mencoba untuk membangun dan mengembangkan kepercayaan diri pada pengikutnya atau bawahannya.

Pendelegasian, cara memotivasi keempat, adalah kebutuhan untuk menyerahkan beberapa wewenangnya kepada bawahan. Pendelegasian memberikan tanggung jawab dan tingkat otonomi kepada pengikutnya. Pendelegasian membantu pemberdayaan pengikut. Proses pemberdayaan membutuhkan leader yang dapat mentransformasi pengikut untuk bisa menjalankan sebagian daripada yang dijalankan oleh leader. Pendelegasian adalah juga strategi memperkaya pekerjaan (enriche jobs). Job enrichment meliputi restrukturisasi pekerjaan dengan sengaja membuat mereka lebih tertantang, termotivasi, dan dihargai. Job Characteritic Model adalah salah satu kerangka teoritikal untuk pengembangan dan pengimplementasian program job enrichment.

Penciptaan tantangan melalui penetapan tujuan (goal-setting), cara memotivasi kelima, adalah sangat dibutuhkan untuk pengimplementasian agenda organisasional dan visi organisasional. Penetapan tujuan adalah metode utama pemotivasian pengikut. Untuk menjadi motivator, tujuan harus tidak hanya menantang, tetapi juga jelas dan spesifik. Di samping menciptakan tantangan, proses penetapan tujuan juga memberikan pengikut dengan arahan yang terperinci

Cara memotivasi bawahan yang keenam atau terakhir adalah rewarding dan punishing yang merupakan faktor penting dalam pemotivasian pengikut untuk mengimplementasian visi. Pengikut yang merasa kompeten dan mampu mencapai visi organisasi akan langsung menyiapkan kesiapannya untuk bertindak jika di beberapa hal mereka menerima reward dari leader-nya.

Leader harus mendesain sistem reward yang konsisten dengan visi organisasi dan mengiringi tujuan. Peran leadership dalam mengalokasikan reward juga menghasilkan dorongan yang kuat untuk bekerja sebab ada pemberdayaan yang potensial. Bawahan yang merasa diberdayakan dengan baik apabila mempunyai leader yang menghargai pencapaian dari stafnya dengan ekspresi memuji dan memberi reward yang nampak tinggi dan ini merupakan cara-cara membangun kepercayaan.

Kadang, leader harus menghukum karyawan yang tidak memiliki kesamaaan dengan visi organisasi dan menyertai tujuan. Hukuman bisa dari mulai yang teringan misalnya berupa teguran dan sampai dengan hukuman yang paling berat adalah pemberhentian. Hukuman sebaiknya tidak menjadi teknik leadership yang utama, sebab riset menunjukkan bahwa reward posisif secara umum lebih efektif daripada hukuman dalam pengelolaan perilaku karyawan dalam jangka panjang.

Pengelolaan Informasi. Pengelolaan infromasi, kategori keempat, implementasi yang kedua, terkait pada banyak aspek dari tanggung jawab dan aktivitas leader, misalnya penilaian dan pemonitoran feedback, perencanaan, dan pengambilan keputusan. Pengumpulan dan pemrosesan informasi mengkonsumsi waktu yang bergitu banyak. 
Leader harus terampil saat pengumpulan informasi yang dibutuhkan dan mengintegrasikan informasi untuk membuat keputusan efektif, meskipun dalam kondisi tertekan, tidak pasti, dan turbulen.

Pengumpulan informasi adalah aspek manajemen informasi, dan mendengarkan adalah metode pengumpulan yang pokok dalam pengumpulan informasi. Saluran komunikasi adalah pembuluh dan arteri dari ide-ide baru. Saluran komunikasi adalah penting dalam pengumpulan ide untuk produk, proses, dan jasa baru. Leader pada setiap level dalam organisasi membuat upaya untuk mendengarkan pada karyawannya dan mengintegrasikan dan bertindak pada informasi yang diterima. Sisi lain dari informasi adalah penyaringan informasi.

Pembangunan Tim. Leader yang ahli pada pembangunan tim (sebagai kategori kelima) yang kooperatif meningkatkan kemungkinan bahwa bawahannya akan tertarik kerja sama untuk mengimplemtasikan visi. Kemampuan untuk membangun tim manajemen yang kohesif adalah sangat penting. Kemampuan membangun tim ini membedakan leader yang berhasil dari leader yang tidak berhasil.

Meningkatkan Perubahan, Inovasi dan Pengambilan Risiko. Ini merupakan kategori terakhir dalam implementasi visi. Leader yang efektifberinisistaif dan melakukan perubahan dan inovasi. Pekerjaan leader adalah mempersiapkan orang dan organisasi untuk berhubungan dengan - menyukai, mengembangkan afektif pada — perubahan. Perubahan datang dalam bentuk yang berbeda-beda. Perubahan mungkin berupa: bentuk produk baru, pasar baru, inovasi teknikal atau memperbaiki produk dan jasa yang ada. Kemampuan leader untuk menciptakan dan mengelola perubahan adalah penting dan krusial tidak hanya untuk mencapai visi tetapi juga untuk keberhasilan dan kelasngungan organisasi. Inovasi harus secara konstan 'diusulkan, diuji, ditolak, dimodifikasi, dan dilakukan' pada organisasi untuk menjadi efektif, karena keberhasilan perusahaan terletak pada kemampuan berinovasi melakukan perubahan.

\section{PERSPEKTIF LAIN DALAM PENGINTEGRASIAN TEORI LEADERSHIP}

Para penulis buku lain, misalnya Yukl (1989, p. 263-288) dalam bab terakhir mencoba me-review dan mengintegrasikan berbagai macam teori leadership dan motivasi. Meskipun lebih ringkas, hasilnya pengintegrasian teori leadership yang telah dilakukan oleh Locke et al. (1991) adalah lebih lengkap. Dalam upaya mengintegrasikan berbagai macam teori, Pfeffer tidak membuat model yang gampang dipahami. Yukl menjelaskan apa pentingnya leadership, overveiw dari berbagai pendapat dari pendekatan-pendakatan yang berbeda, inti-inti antar pendekatan, dan implikasi perbaikan leadership. Dalam buku tersebut belum dapat diperoleh gambaran yang lebih komprehensif jika dibandingkan dengan leadership model (Locke, et al.). Kemudian, Yukl (1989, p. 274) dalam artikelnya yang berjudul Managerial Leadership: A Review of Theory and Research, mencoba mengintegrasikan kerangka konsepsual leadership. Dalam Gambar 2, kita dapat melihat lebih jelas mengenai kerangka pengintegrasian kerangka konsepsual leadership (yang telah disederhanakan) menurut Yukl. 




Gambar 2. Pengintegrasian Kerangka Konsepsual Leadership (Yukl, 1989, p. 274)

Dalam Gambar 2, pengintegrasian kerangka konsepsual yang ditawarkan oleh Yuk1 (1989) bersifat sangat kompleks. Dengan demikian dari azaz parsimoni, leadership model yang ditawarkan oleh Locke et.al. (1991) lebih gampang dipahami dan dicerna.

\section{PERBAIKAN MODEL LEADERSHIP YANG LEBIH KOMPREHENSIP DAN PARSIMONI}

Yocke, at al. (1991) mencoba mengintegrasikan berbagai macam teori motivasi dan teori leadership. Hasil pengintegrasiannya dirangkum dalam suatu model yang disebut Leadership model. Leadership seperti di Gambar 1 berisi empat bagian, yaitu: 1) motive dan trait, 2) knowledge, visi, dan ability, 3) visi, dan 4) implementasi visi. Seperti yang sudah diutarakan sendiri oleh penulis buku ini bahwa isi buku ini berupa pokok-pokoknya saja. Dengan demikian tentu tidak bisa kita harapkan dari buku ini adanya penjelasan yang rinci yang bisa menjadi panduan atau rujukan untuk berbagai masalah dalam leadership. Contoh-contoh yang diberikan juga belum memadai, sehingga contoh-contoh yang ada di buku ini belum cukup untuk menjadi referensi utama untuk dapat menjawab berbagai permasalahan di bidang leadership. Apabila kita ingin memperoleh jawaban yang lebih tuntas terhadap berbagai persoalan mengenai leadership kita perlu mencari tambahan buku lain yang lebih lengkap dan rinci.

Tahap keempat leadership model di bukunya Locke et al. ini adalah implementasi visi, sebagai langkah berikutnya dari visi. Langkah-langkah implementasi visinya adalah: 1) agenda development, 2) structuring, 3), selecting, acculturing, and training, 4) motivating (authority, role modeling, building selft-confidence, delegating, goal setting, rewarding 
and punishing), 5) managing information (gathering, disseminating), 6) team building, dan 7) promoting change, innovation, and risk-taking. Kemudian, apabila kita lihat isi buku Strategic Leadership (Davies, 1991) menyebutkan bahwa pengimplementasian visi adalah dengan menggunakan strategic leadership, yang maknanya jauh lebih lengkap dari apa yang telah dituliskan oleh Locke et al. dalam tahap keempat leadership. Dengan demikian, kita dapat mengatakan dalam aspek pengimplementasian visi dalam bukunya Locke ini, meskipun sudah baik, tetapi tidak selengkap pengimplementasian visi menurut Davies (1991).

Davies (1991) menjelaskan bahwa untuk mengimplementasikan visi dengan menggunakan pendekatan strategic leadership. Dalam strategic leadership, Davies (1991) menjelaskan tentang: 1) strategi dalam dunia persaingan, 2) tugas strategik, 3) peran leader dalam formulasi dan implementasi strategi, 4) strategi dan struktur, 5) perencanaan strategik: bagaimana mengorganisasi dalam perusahaan, 6) Teknik perencanaan strategik dan aplikasi praktiknya, dan 7) manajemen strategik.

Strategi dalam dunia persaingan yang dipaparkan Davies bahwa lingkungan persaingan yang begitu dahsyat harus menjadi dasar untuk menyusun strategi perusahaan (corporate strategy). Tugas-tugas strategik mengupas pendefinisian lingkungan perusahaan, penilaian persaingan, mengembangkan dan mengevaluasi pilihan-pilihan, menilai risiko, menentukan skala prioritas, menentukan tujuan, dan mengelaborasi strategi-strategi untuk mencapai tujuan perusahaan. Dalam bukunya Davies (1991), memformulasikan dan mengimplementasikan strategi dibahas lebih rinci jika dibandingkan dengan bukunya Locke et al. Hubungan antara strategi dan struktur juga mendapat perhatian yang cukup di bukunya Davies. Dengan adanya pertimbangan-pertimbangan tersebut di atas, saya mencoba mengkombinasikan antara leadership model (Locke et al., 1991) dan strategic leadership (Davies, 1991). Kombinasinya adalah tahap 4 dari leadership model yang berupa implementasi visi digantikan dengan strategic leadership. Agar dapat diperoleh gambaran yang lebih utuh, kita dapat melihat Gambar 3, yang merupakan modifikasi leadership. Modifikasi ini diharapkan menjadi perbaikan model leadership yang lebih komprehensip dan parsimoni 
Motives and Traits

\section{Motif:}

Drive (achievement, ambition, energy, tenacity, initiative)

Leadership Motivation (socialized vs personalized)

\section{Sifat (Traits)}

Kejujuran dan Integritas

Percaya Diri

Originalitas dan Kreativitas

Fleksibilitas dan Adaptasi

Karisma

\section{KSAs}

$\frac{\text { Pengetahuan (Knowledge - K) }}{\text { Technology expertise }}$

Knowledge of organizational and industry, gained through experience

\section{Keterampilan (Skill - S)}

Keterampilan Orang (listening, oral communication, networkbuilding, conflict management, assessment)

Keterampilan Managemen (problem-solving, decision-

making, goal setting, planning)

Kemampuan (Ability-A)

Cognitive ability/intelligence

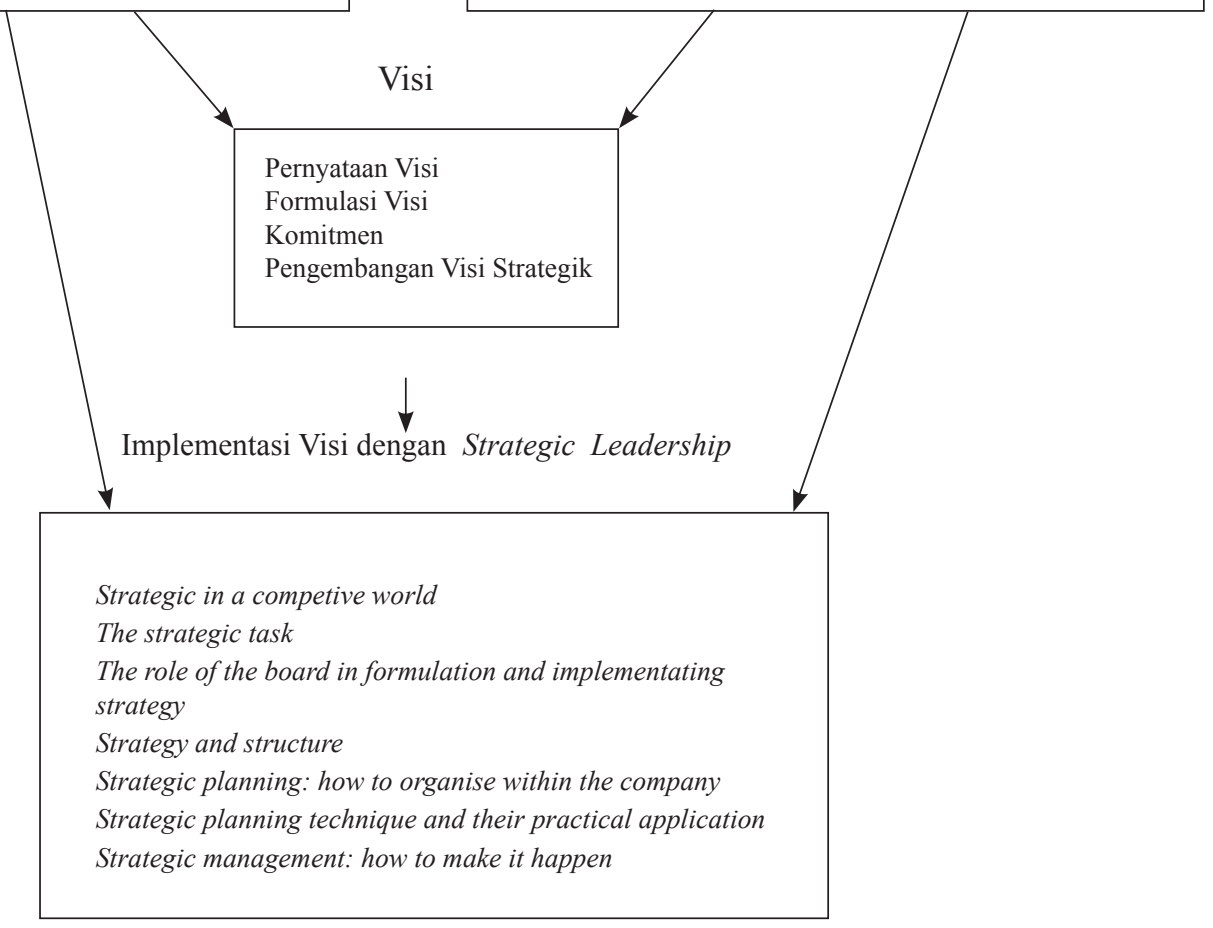

Gambar 3. Perbaikan Leadership Model yang Lebih Komprehensip dan Parsimoni

\section{KESIMPULAN}

Model leadership Locke, et al. (1991) mempunyai kelebihan dalam hal penyampaian. Teori-teori dan hasil riset mengenai leadership dan motivasi yang telah dikutip oleh penulis buku ini dapat ditulis kembali dalam bahasa penyampaian yang sangat menarik. Dengan menggunakan bahasa yang sederhana, kalimat yang pendek-pendek, dan alur kata yang bagus, maka maksud dari penulis yang telah disampaikan melalui buku ini mudah dicerna dan dipahami.

Locke, et al. (1991) mengintegrasikan teori-teori yang mendukung teori teori leadership, misalnya teori-teori motivasi yang ada, dan juga teori-teori yang terkait dengan leadership lainya. Pengintegrasian dari berbagai teori tersebut yang kemudian 
disederhanakan dalam suatu model yang disebut: leadership model. Leadership model seperti di Gambar 1 berisi empat bagian, yaitu: 1) motive dan trait, 2) knowledge, visition, dan ability, 3) visi, dan 4) implementasi visi.

Melalui Leadership model yang ditawarkan oleh Locke et al. (1991) dapat dikatakan bahwa baik tidaknya visi leader dalam menjalankan organisasi sangat tergantung pada baik tidaknya motif dan sifat (trait), pengetahuan (knowledge), keterampilan (skill), dan kemampuan (ability) yang dimiliki leaders. Kemudian, baik tidaknya implementasi visi yang dilakukan oleh leader juga tergantung pada baik tidaknya motif dan sifat (trait), pengetahuan (knowledge), keterampilan (skill), kemampuan (ability), dan visi yang dimiliki oleh leader.

Seperti yang sudah diutarakan sendiri oleh Locke, et al. (1991), isi karyanya ini berupa pokok-pokoknya saja. Dengan demikian tentu tidak bisa kita harapkan adanya penjelasan yang rinci yang bisa menjadi panduan atau rujukan untuk berbagai masalah dalam leadership. Contoh-contoh yang diberikan juga belum memadai, sehingga contohcontoh yang ada belum cukup untuk menjadi referensi utama untuk dapat menjawab berbagai permasalahan di bidang leadership.

Apabila kita lihat isi buku Strategic Leadership (Davies, 1991) menyebutkan bahwa pengimplementasian visi dengan menggunakan strategic leadership, yang maknanya jauh lebih lengkap dari apa yang telah dituliskan oleh Locke et al. dalam tahap keempat leadership. Dengan demikian, kita dapat mengatakan dalam aspek pengimplementasian visi dalam bukunya Locke et al. ini isinya tidak selengkap pengimplementasian visi menurut Davies (1991). Dengan adanya pertimbangan-pertimbangan tersebut di atas, artikel ini mencoba mengkombinasikan antara leadership model dan strategic leadership dari Davies. Kombinasinya adalah tahap 4 dari leadership model yang berupa implementasi visi digantikan dengan strategic leadership, dan hasilnya kombinasinya dapat dilihat di Gambar 3. Dengan modifikasi ini diharapkan apa yang sudah baik di leadership model akan semakin komprehensip dan parsimoni.

\section{REFERENSI}

Davies, Adrian H. 1991. Strategic Leadership. Singapore: Woodhead-Faulkner(Publisher) Limted.

Jago, Arthur G. 1982. Leadership: Perspectives in Tehory and Research . Management Science. Vol. 28. No. 3.

Karmel, Barbara. 1978. Leadership: A Challenge to Traditional Research Methods and Assumption. Academy of Mangement Review. - July

Locke, et. al. 1991. The Essence of Leadership. Canada: Lexington Book An Imprint od Macmillan, Inc.

Meindl, James R., et. al. 1985. The Romance of Leadership. Administrative Science Quaterly, 30: 78-102.

Pfeffer, Standord. 1982. Organizational and Organizational Theory. Mashachusetts: Pitman Publishing. Inc.

. 1975. The Ambiguity of Leadership. Acadeny of Management Review 2, No. 1, pp. 104-12 
Smircich, Linda and Gareth Morgan. 1982. Leadership: The Management of Meaning. The Journal of Applied Behavioral Science, Vol. 18, Number 3.

Yukl, Gary. 1989. Leadership in Organization, Second Edition. New Jersey: Prentice Hall. . 1989. Managerial Leadership: A Review of Theory and Research. Journal of Manjament, Vo. 15, No. 2. 251-289. 
